Shigeo Kimura,

Dean, Faculty of Production Systems Engineering and Sciences,

Vice-President of Komatsu University, Japan, email:shigeo.kimura@komatsu-u.ac.jp

Badenikov A.V.,

Professor, rector of Angarsk State Technical University, Russia, email: rector@angtu.ru

\title{
COOPERATION PROSPECTS BETWEEN ANGARSK STATE TECHNICAL UNIVERSITY AND UNIVERSITY OF KOMATSU CITY (JAPAN)
}

\begin{abstract}
The article considers the tasks and prospects of cooperation in the scientific and educational fields between the universities of Komatsu and Angarsk.It should be noted that cooperation between universities is based on high principles of enlightenment and humanism.

Keywords: international cooperation, Komatsu University, ASTU, development of scientific and technical cooperation.

Long-standing friendly relations have developed between the Angarsk and Komatsu Cities [1-5]. In the May of 2006 the Friendship Society «Angarsk-Komatsu» was established in Angarsk. In 2017 the agreement on the twin-town relations was signed.Bilateral ties between cities can become a solid foundation for university research collaboration.

Komatsu University was established in 2018. The university consists of three faculties: Production Systems Engineering and Sciences, Health Sciences and International Cultural Communication.

Angarsk State Technical University was founded in 1991 and it consists of three faculties: the Faculty of Technical Cybernetics, the Faculty of Technology and the Faculty of Management and Business. The university also includes a laboratory for hygiene and risk assessment for the health of the population from exposure to a chemical environmental factor. Our graduates work in the fields of chemical industry, oil refining, electric power industry, ecology, information technology, automation of technological processes, construction, management of automobile transport, and economics.
\end{abstract}

The cooperation objectives taking into account the specifics of universities and regions are the development of scientific and technical interaction, integration into the world system of higher education, the promotion of the international educational process, the establishment of business contacts between cities, the creation of the creative ties and the exchange of scientific and technical information.

Cooperation prospective areas between the universities of Komatsu and Angarsk are such as:

1) exchange of students on the coordinated programs, the combined training in undergraduate, graduate, postgraduate studies; teachers;

2) academic staff development, conduct the international internships for

3) development and conduct the joint scientific and educational projects in various fields of activity;

4) training methods exchange between the academic staff of universities; 
5) information exchange on the prospects of scientific areas that are being developed at Komatsu University and ASTU and on which they plan to expand contacts in the field of technical, exact and applied sciences; also the exchange of information about inventions, progressive technical solutions of scientists from the University of Komatsu and ASTU;

6) information exchange on international conferences, seminars and symposia in Japan and Russia; participation of specialists from Komatsu University and ASTU in the organization and conduct of international conferences, seminars and symposia;

7) enhanced cooperation in the publication of scientific and technical works of scientists of the University of Komatsu and ASTU in collections of scientific works, journals and monographs;

8) collaboration in providing advisory services to government and private organizations in the areas of mutual competence.

To achieve the cooperation goals the universities have to ensure within their capabilities the creation of the necessary organizational and economic conditions, in particular, the availability of the necessary material and technical resources to deepen and expand cooperation.

In the cooperation implementation the maintenance of the rights and legitimate interests of Komatsu University and ASTU within the framework of the current legislation of Japan and the Russian Federation is guaranteed.

Cooperation between universities is based on the high principles of enlightenment and humanism.

We hope that in the future cooperation between universities will be long-term and fruitful.

\section{REFERENCES}

1. Angarsk and Komatsu can become twin cities. Available at: https://irkobl.ru/news/archiv/59596/?type=special (accessed 16 March 2020).

2. A delegation from the Japanese cities of Komatsu and Kanazawa visited Angarsk.Available at: https://angarsk-adm.ru/gorodskoy-okrug/informatsiya / 1056 / (accessed 16 March 2020).

3. A delegation from the Japanese twin-city of Komatsu arrived in Angarsk.Available at: https://liveangarsk.ru/news/20180806/v-angarske-poyav (accessed 16 March 2020).

4. About the trip of the Angarsk delegation to Japan. Available at: https://angvremya.ru/society/19125-delovoy-marshrut.html (accessed16 March 2020).

5. An official twinning agreement was signed between the Japanese city of Komatsu and Angarsk. Available at: https://news.rambler.ru/other/38479486podpisano-ofitsialnoe-soglashenie-o-pobratimskih-svyazyah- mezhdu-yaponskim gorodom-komatsu-i-angarskom / (accessed 16 March 2020). 